\title{
DISTRIBUTION OF MOULDS AND MYCOTOXINS IN MAIZE GRAIN SILAGE IN THE TRENCH SILO
}

\author{
V. Krnjaja ${ }^{1}$, J. Lević ${ }^{2}$ S. Stanković ${ }^{2}$, T. Petrović ${ }^{3}$, Lj. Stojanovićc ${ }^{1}$ Č. \\ Radović $^{1}$, M. Gogić ${ }^{1}$ \\ ${ }^{1}$ Institute for Animal Husbandry, Autoput 16, 11080, Belgrade-Zemun, Serbia \\ ${ }^{2}$ Maize Research Institute „Zemun Polje”, Slobodana Bajića 1, 11185, Belgrade-Zemun, Serbia \\ ${ }^{3}$ Institute of Food Technology and Biochemistry, Faculty of Agriculture, University of Belgrade, \\ Nemanjina 6, 11080, Belgrade-Zemun, Serbia \\ Corresponding author: VesnaKrnjaja.IZS@gmail.com \\ Original scientific paper
}

\begin{abstract}
In this study the mycological and mycotoxicological contamination of maize silage samples collected from the bottom (BL), middle (ML) and top (TL) layer in the silage trench silo was studied. Mycological testing of the silage contamination showed the presence of five potential toxigenic fungi of the genera, Aspergillus, Fusarium, Mucor, Penicillium and Rhizopus with their total number ranging from 1 to $10 \times 10^{3} \mathrm{CFU} \mathrm{g}^{-1}$. Also, four mycotoxins were detected as followed, aflatoxin B1 (AFB1), zearalenone (ZON), deoxynivalenol (DON) and fumonisin B1 (FB1). Mycotoxins AFB1 and FB1 were detected as $100 \%$ positive in all the samples tested. An average concentration of AFB1 was $2.31 \mu \mathrm{g} \mathrm{kg}^{-1}, 2.51 \mu \mathrm{g} \mathrm{kg}^{-1}$ and $2.81 \mu \mathrm{g} \mathrm{kg}^{-1}$ in BL, ML and TL respectively, while the concentration of FB1 was $1292.00 \mu \mathrm{g} \mathrm{kg}^{-1}, 1298.00 \mu \mathrm{g} \mathrm{kg}^{-1}$ and $1902.00 \mu \mathrm{g} \mathrm{kg}^{-1}$ in $\mathrm{BL}, \mathrm{TL}$ and ML respectively. Average concentration of toxin $\mathrm{ZON}$ in positive samples was $15.69 \mu \mathrm{g} \mathrm{kg}^{-1}$ in BL and $30.68 \mu \mathrm{g} \mathrm{kg}^{-1}$ in ML, while its presence in the samples taken from the top layer was not detected. An average concentration of DON toxin in positive samples were in the range of $41.71 \mu \mathrm{g} \mathrm{kg}^{-1}$ for TL, $79.20 \mu \mathrm{g}$ $\mathrm{kg}^{-1}$ for ML, while it was $97.00 \mu \mathrm{g} \mathrm{kg}^{-1}$ for BL. There was no statistically significant correlation between moisture content and total number of moulds and concentrations of certain mycotoxins. However, statistically highly significant correlations between the total number of moulds and $\mathrm{AFB}_{1}$ concentration $(\mathrm{r}=1.0)$, ZON $(r=0.99)$ and $\mathrm{FB}_{1}(\mathrm{r}=0.91)$ were established, while weak correlation was obtained in the case of DON and total mould counts $(r=0.54)$.
\end{abstract}

Key words: maize grain silage, moulds, mycotoxins, distribution

\section{Introduction}

After rice and wheat, maize is consider as an important crop in the World, (Reddy and Salleh, 2011), and the most important component of animal feed. It has 
been used in human nutrition, and more recently as a raw material in energy production. Maize as one of the most important agricultural crops in Serbia, has been growing on an area of 1.24 M ha (Statistical Office of the Republic of Serbia, 2011).

Silage of maize is stored under anaerobic conditions with addition of bacterial inoculants usually contain one or more species of homofermentative lactic acid bacteria (LAB) that are fast and efficient producers of lactic acid. The most common inoculants are Lactobacillus plantarum and other Lactobacillus spp. combined with Enterococcus, Lactococcus and Pediococcus species. These inoculants can increase the rate of acidification and reduce the final $\mathrm{pH}$ and protein degradation in silage (Driehuis et al., 1997). The main objective in application of these $\mathrm{LAB}$ inoculants is to reduce the risk of clostridial and fungal proliferation and enhance the nutritional value of silage. However, poor conditions during ensiling, especially in mature silage during the 11 months, followed by exposure of silage to condensation, heating, leakage of rainwater, infection by insects can lead to proliferation of toxigenic fungi (moulds), biosynthesis of mycotoxins as well as reducuction of nutritional value of silage (Cleveland et al., 2003; Frisvad et al., 2006).

Maize grain is very suitable environment for the growth of pathogenic fungi and their secondary metabolites (mycotoxins) can contaminate plants in a field or grain during storage (pre- or post-harvested contamination). Moulds, likewise, can occur in fermented foods such as maize silage and maize feed with a high moisture content (Roigé et al., 2009). Mycotoxins are a particularly important problem in livestock production when the environmental conditions during the vegetation season are favourable for the development of toxigenic fungi in grain crops. In the body of animals and humans, mycotoxins are mostly introduced through contaminated food through spores and fragments of mycelium (Sinovec and Resanović, 2006). Diseases caused by these mycotoxins are known as mycotoxicosis, while fungal infections in humans and animals are known as mycosis (Nogaim et al., 2011).

Fungi that are producers of mycotoxins belong to the following genera: Alternaria, Aspergillus, Fusarium and Penicillium. Toxigenic Alternaria and Fusarium species are often categorized as field fungi, whereas Aspergillus and Penicillium species are considered to be storage fungi (Logrieco et al., 2003). Although more than 300 mycotoxins have been identified, less than 20 is of particular importance because of their natural occurrence and toxicity (Bottalico, 1998; Whitlow and Hagler, 2002).

In the grain, mycotoxins with the most detrimental impact on animal and human health are aflatoxins, ochratoxins, fumonisins, zearalenone (ZON), deoxynivalenol (DON), T-2 toxin and other trichothecenes and ergot alkaloids. Aflatoxins produced by Aspergillus spp. are the most harmful mycotoxins due to their carcinogenic activity. Among the trichothecenes, DON, T-2 toxin, H-2 toxin and diacetoxyscirpenol (DAS) are the most important as potential inhibitors of 
protein synthesis in eucaryota (Bennet and Klich, 2003). The mainly product of Fusarium species are trichothecenes and ZON which causes hyperestrogenism, the oestrogenic syndrome in pigs. Ochratoxin A, produced by numerous Aspergillus and Penicillium species has also demonstrated carcinogenic activity for humans (Marquardt and Frohlich, 1992). Recently identified and described mycotoxins are fumonisins that cause several animal diseases, such as equine leukoencephalomalacia (ELEM) in horses, and porcine pulmonary oedema (PPE) in pigs. Fumonisins are mycotoxins produced by numerous species of Fusarium genus (Marasas, 1988; Binder, 2007) while ergot alkaloids are mycotoxins produced by fungi of the genus Claviceps (Scott, 2007).

Considering that the literature in Serbia on presence of mycotoxins in maize grain silage is scarce, and also due to unevenly distribution of mycotoxins in the silage, the main objective of this study was to investigate the presence of aflatoxin $\mathrm{B} 1$ (AFB1), zearalenone ( $\mathrm{ZON})$, deoxyinivalenol (DON) and fumonisin B1 (FB1) mycotoxins in the samples of maize grain silage taken from different layers (bottom, middle and top) of the trench silo, as well as to established their mutual relation or co-occurrence. In addition, the mutual correlation between the moisture content and total mould counts with total concentration of mycotoxins in different layers of silage has also been performed.

\section{Materials and Methods}

A total of 30 samples of maize grain silage were taken for mycological and mycotoxicological analysis. The samples were collected in March 2012 from the trench silo, storing the silage intended for pigs feeding, located on the farm of the Institute for Animal Husbandry, Belgrade. The dimensions of the trench silo was $40 \times 8 \times 3$ m (length $\times$ width $\times$ height) with a capacity of about 900 tons. According to the Commission Regulation (EC) No 401/2006 (European Commission, 2006) 10 samples of average weight of $1 \mathrm{~kg}$ per sample of silage were taken through random sampling from three different layers of the trench silo (bottom $-100 \mathrm{~cm}$, middle $-100 \mathrm{~cm}$ and top $-100 \mathrm{~cm}$ ). The samples were kept in plastic bags at $4^{\circ} \mathrm{C}$, prior to the analysis. Fresh samples were used for standard mycological analysis. The total moisture content was determined by drying 3-5 g of sample in the oven at $105^{\circ} \mathrm{C}$ (SRPS ISO 6496:2001, 2001), while mycotoxicological analysis were done by drying the samples at $60^{\circ} \mathrm{C}$ for 72 hours.

Mycological analysis was performed according to the standard methods SRPS ISO 21527-1:2008 (2008). The sample was homogenized in sterile saline $(0.85 \% \mathrm{NaCl})$ for 2 minutes in the orbital shaker (GFL 3015, Germany). After homogenization step a serial dilution method was done and $1 \mathrm{ml}$ of dilution of $10^{-3}$ and $10^{-4}$ were poured over the surface of Dichloran Rose Bengal Chloramphenicol Agar (DRBC). After incubation at $25^{\circ} \mathrm{C}$ for 5-7 days, individual species and the total number (count) of moulds were identified. The morphological characteristic 
of isolated species were identified based on macroscopic (colony appearance) and microscopic (spores forming) investigations (Watanabe, 1994).

The presence of AFB1, ZON, DON and FB1 was studied by immuneenzyme (ELISA) method. Five grams of sample was mixed with $1 \mathrm{~g}$ of $\mathrm{NaCl}$ and homogenized in $25 \mathrm{ml}$ of $70 \%$ methanol in a $250 \mathrm{ml}$ Erlenmeyer flask on the orbital shaker (GFL 3015, Germany) for 30 minutes. Homogenate was filtered through a Whatman filter paper 1 . The filtrate was further analysed according to the manufacturer's instructions Celery Techna ${ }^{\circledR}$ ELISA kits. Absorbance was measured at a wavelength of $450 \mathrm{~nm}$ on an ELISA reader spectrophotometer (Biotek EL x 800TM, USA).

Correlation between individual values obtained for moisture content, total mould counts and mycotoxins was determined using Pearson's correlation coefficient.

\section{Results and Discussion}

Moisture content of maize grain silage in the trench silo gradually decreased from the top to the bottom layer. The highest value of $72.02 \%$ was obtained in the top layer, while it was $68.53 \%$ and 67.61 in the middle and the bottom layer, respectively.

According to mycological analysis of tested samples the total number of moulds per gram was in the range of 4-7 $\times 10^{3}, 2-10 \times 10^{3}$ and $1-5 \times 10^{3}$ for the samples in the bottom layer (BL), middle layer (ML) and top layer of the trench silo (TL), respectively (Table 1 ). By microscopic examination the five genera of fungi were determined as followed: Aspergillus, Fusarium, Mucor, Penicillium and Rhizopus, of which the genera Aspergillus, Penicillium and Rhizopus were identified in the samples from the bottom layer, then Mucor and Penicillium in the samples from the middle layer and Fusarium, Mucor and Penicillium in the samples from the top layer in the trench silo.

In mycological studies of 18 samples of feed mixture intended for fattening swine which were collected from three different provinces of Serbia, Milićević et al. (2010) have performed the total fungal counts of $10^{5}$ to $40 \times 10^{5}$ and most frequently isolated were species of genus Penicillium (94.4\%) followed by species of genera Fusarium (55.5\%) and Paecilomyces (44.4\%). These are in agreement with our results since from all tested layers, Penicillium species were isolated. According to data of Roigé et al. (2009) Penicillium and Aspergillus were the most prevalent moulds isolated from fermented feed in USA and Europe. It have been established that Aspergillus, Penicillium and Mucor were the most common species isolated from the maize silage with a total of 131.600 and 9920 colonies per gram of dry silage on each of two media, Czapek's and Sabouraud's dextrose agar ( $E l$ Shanawany et al. 2005). In addition, González-Pereyra et al. $(2007,2011)$ have determined the total number of fungi from 0 to $1 \times 10^{8} \mathrm{CFUg}^{-1}$ in samples of maize 
silage from trench silo, where the most common isolated species were from the genera of Aspergillus (78\%) and Fusarium (62\%).

Table 1. The moisture content and total mould counts in samples of maize grain silage from the bottom (BL), middle (ML) and top (TL) layer in the trench silo

\begin{tabular}{|c|c|c|}
\hline $\begin{array}{c}\text { Samples of maize grain } \\
\text { silage }\end{array}$ & $\begin{array}{c}\text { Moisture content } \\
(\%)\end{array}$ & $\begin{array}{c}\text { Range of total mould counts / g silage } \\
\left.\text { sample (CFU } \mathbf{g}^{-\mathbf{1}}\right)\end{array}$ \\
\hline BL & 72.02 & $4-7 \times 10^{3}$ \\
\hline ML & 68.53 & $2-10 \times 10^{3}$ \\
\hline TL & 67.61 & $1-5 \times 10^{3}$ \\
\hline
\end{tabular}

Table 2. Concentration of aflatoxin B1 (AFB1), zearalenone (ZON), deoxynivalenol (DON) and fumonisin B1 (FB1) in samples of maize grain silage from the bottom (BL), middle (ML) and top (TL) layer in the trench silo

\begin{tabular}{|c|c|c|c|c|c|c|c|c|c|c|c|c|}
\hline \multirow{2}{*}{ Item } & \multicolumn{3}{|c|}{ AFB1 } & \multicolumn{3}{|c|}{ ZON } & \multicolumn{3}{c|}{ DON } & \multicolumn{3}{c|}{ FB1 } \\
\cline { 2 - 12 } & BL & ML & TL & BL & ML & TL & BL & ML & TL & BL & ML & TL \\
\hline $\begin{array}{c}\text { Sample } \\
\text { size }^{\mathbf{a}}\end{array}$ & $10 / 10$ & $10 / 10$ & $10 / 10$ & $1 / 10$ & $6 / 10$ & $0 / 10$ & $3 / 10$ & $10 / 10$ & $7 / 10$ & $10 / 10$ & $10 / 10$ & $10 / 10$ \\
\hline $\begin{array}{c}\text { Incidence } \\
(\%)\end{array}$ & 100 & 100 & 100 & 10 & 60 & 0 & 30 & 100 & 70 & 100 & 100 & 100 \\
\hline $\begin{array}{c}\mathbf{M e a n}^{\mathbf{b}}(\boldsymbol{\mu g} \\
\left.\mathbf{k g}^{-1}\right)\end{array}$ & 2.51 & 2.81 & 2.31 & 15.69 & 30.68 & 0 & 97.00 & 79.20 & 41.71 & 1292.00 & 1902.00 & 1298.00 \\
\hline
\end{tabular}

${ }^{\text {a }}$ Number of positive samples/Number of total samples

${ }^{\mathrm{b}}$ Mean concentration in positive samples

Mycotoxicological analysis reveled that all mycotoxins tested were presented in all three layers of the trench silo, with exeption of DON toxin that was not detected in the top layer. It was established that AFB1 was $100 \%$ presented in all layers with an average concentration of $2.31 \mu \mathrm{g} \mathrm{kg}$,, $2.51 \mu \mathrm{g} \mathrm{kg}^{-1}$ and $2.81 \mu \mathrm{g}$ $\mathrm{kg}^{-1}$ in TL, BL and ML, respectively. The presence of ZON was in the range of $0 \%$ in TL while it was $60 \%$ in ML with mean concentrations in positive samples from $15.69 \mu \mathrm{g} \mathrm{kg}{ }^{-1}$ in BL to $30.68 \mu \mathrm{g} \mathrm{kg}^{-1}$ in ML. In the tested layers DON was present from $30 \%$ in BL to $100 \%$ in ML, with an average concentration of $41.71 \mu \mathrm{g} \mathrm{kg}{ }^{-1}$, $79.20 \mu \mathrm{g} \mathrm{kg}^{-1}$ and $97.00 \mu \mathrm{g} \mathrm{kg}^{-1}$ in the TL, ML and BL, respectively. Also, the incidence of FB1 was $100 \%$ in all layers of silage in the trench silo with an average concentration showed in Table 2.

According to the Regulation on amendment of Regulation on the maximum allowed levels of residue of pesticides in food and animal feed for which maximum allowed quantities of residue of products for plant protection are regulated (Official Gazette of RS, 2011), it can be concluded that in all analysed silage samples, the concentrations of tested mycotoxins were under the acceptable level.

Statistically significant correlation was not found between the moisture content and total mould counts, as well as between the moisture content and $\mathrm{AFB}_{1}$ 
concentration $(\mathrm{r}=0.08)$, and between moisture content and ZON concentrations $(\mathrm{r}$ $=0.21)$. In the case of $\mathrm{FB}_{1}$ negative correlation with respect to moisture content $(\mathrm{r}$ $=-0.33$ ) was established. In addition there was no statistically significant correlation between either ZON and DON $(r=0.08)$, and between $\mathrm{AFB}_{1}$ and $\mathrm{FB}_{1}(\mathrm{r}$ $=0.30)$. However, a positive correlation was found $(\mathrm{r}=0.86)$ between the moisture content and the concentration of DON, depending on the tested layer of silage. Correlation between the concentrations of AFB1, $\mathrm{FB}_{1}$ and $\mathrm{ZON}$ and total mould counts in individual layers was statistically highly significant $(\mathrm{r}=1.0, \mathrm{r}=0.99$ and $\mathrm{r}=0.91$, respectively), while it was weak in the case of DON and total mould counts $(\mathrm{r}=0.54)$.

Garon et al. (2006) were identified about 20 species of fungi from maize silage, stored during the period of nine month. They reported the potentially toxigenic ability in Aspergillus, Fusarium and Monascus species, which produced mycotoxins AFB1 (4-34 $\left.\mu \mathrm{g} \mathrm{kg}^{-1}\right)$, ZON (23-41 $\left.\mathrm{g} \mathrm{kg}^{-1}\right)$ and DON (100-213 $\mu \mathrm{g} \mathrm{kg}$ $\left.{ }^{1}\right)$. In addition, analysing the presence of AFB1 in silage samples, GonzálezPereyra et al. (2007) have found their low concentrations $\left(<10 \mu \mathrm{g} \mathrm{kg}^{-1}\right)$ in the top and bottom layers, while in the middle layer only six samples (17\%) possessed concentrations of AFB1 from 1.43 to $155.78 \mu \mathrm{g} \mathrm{kg}^{-1}$. Mycotoxins from Fusarium species (ZON, DON and FB1) in post fermented silage samples were presented at a frequency of $90 \%$, with their concentrations ranging from 340 to $2490 \mu \mathrm{g} \mathrm{kg}^{-1}, 30$ to $870 \mu \mathrm{g} \mathrm{kg}^{-1}$ and 0 to $350 \mu \mathrm{g} \mathrm{kg}^{-1}$ for the FB1, DON and ZON, respectively. ZON, DON and FB1 co-occurred in $83.5 \%$ of the samples, whereas $16.5 \%$ samples showed only ZON and FB1 co-contamination (González-Pereyra et al., 2007). In the mycotoxicological analyses of samples of maize silage from the trench silo, it was found $14 \%$ of samples contaminated with AFB1 and two samples that exceeded the recommended value. FB1 was detected in the recommended concentrations, while ZON and DON were not detected (González-Pereyra et al. 2011). The presence of $Z O N$ and DON in the range of 200 to $5000 \mu \mathrm{g} \mathrm{kg}^{-1}$ and 250 to $2500 \mu \mathrm{g} \mathrm{kg}^{-1}$, respectively was detected in the feed mixtures for pig taken from three localities in Serbia (Milićević et al., 2010).

Fungal growth and mycotoxin contamination are the consequence of an interaction among the fungus, host and environment. The appropriate combination of these factors, determine infection and colonization of the substrate and type and amount of mycotoxin produced. The presence of moulds on a food or feed product does not necessarily indicate the presence of mycotoxins, as well as the absence of moulds does not necessarily mean the absence of mycotoxins (Harley, 1997). Also, mycotoxin content is not related to the amount of mould present (Tarr, 2006). Đilas et al. (2001) in 1999 have reported that although feed mixtures for pig, poultry and cattle had not been safety from the microbiological point of view, because of the presence of Fusarium (58\%), Penicillium (46\%) and Aspergillus $(43 \%)$ species, it did not contained any of the analysed mycotoxins (aflatoxin B1, B2, G1 and G2, ochratoxin A, ZON and trichothecenes). On the other hand, in this study it should be observed that Aspergillus spp. and/or Fusarium spp. were not 
identified in all tested layers, even if their toxins AFB1 and fusarotoxins were detected. This can be explained by higher contamination of maize crop still in the field with these types of moulds and their mycotoxins. Pre-harvest mould growth and aflatoxin and fusarotoxins production in maize are favoured by warm ambient temperatures and prolonged drought conditions that were typical in Serbia during summer 2011 according to the Republic Hydrometeorological Service of Serbia.

\section{Conclusion}

The results in this study showed that the values of moisture content, total mould counts and mycotoxin concentrations of $\mathrm{AFB}_{1}, \mathrm{ZON}, \mathrm{DON}$ and $\mathrm{FB}_{1}$ had been changing depending on the layer of maize silage in the trench silo. The moisture content of silage gradually decreased from the top $(72.02 \%)$ toward the bottom layer $(67.61 \%)$, while for the most other parameters the obtained values were highest in the middle layer, with the exception of presence of DON. The greatest difference in the incidence of mycotoxins in the layers was in the case of ZON since its presence was 10,60 and $0 \%$ in the bottom, middle and top layer, respectively. In addition, in all samples tested the concentration of mycotoxins was directly correlated with the total number of moulds per individual layers of silage ( $\mathrm{r}$ $=0.54-1.0)$, as well as the concentration of DON and moisture content $(\mathrm{r}=0.86)$.

According to our results it could be recommended that the maize grain silage should be taken vertically or simultaneously from all layers of the trench silo in order to reduce the concentrations of mycotoxin in average.

Future research should be focus on the assessment of the level of concentration of mycotoxins introduced from the silage into the feed mixture. Also, it should be important to compare the quality of silage before and after fermentation (pre- and post-fermentation). For this reason, the information about the presence of moulds and mycotoxins in maize silage could be very significant in the risk assessment on human and animal health.

\section{Acknowledgment}

This work was supported by the Ministry of Education, Science and Technological Development, Republic of Serbia within projects TR-31023, TR31081 and TR-46010. 


\title{
Distribucija plesni i mikotoksina u silaži od zrna kukuruza u silo-trenču
}

\author{
V. Krnjaja, J. Lević, S. Stanković, T. Petrović, Lj. Stojanović, Č. Radović, M. Gogić
}

\section{Rezime}

U radu je ispitivana mikološka i mikotoksikološka kontaminacija uzoraka silaže od zrna kukuruza sakupljenih iz donjeg (DS), srednjeg (SS) i gornjeg (GS) sloja silaže u silo-trenču. Mikološkim ispitivanjima kontaminacije silaže ustanovljeno je prisustvo pet potencijalno toksigenih rodova plesni, Aspergillus, Fusarium, Mucor, Penicillium i Rhizopus sa ukupnim brojem od 1-10 x $10^{3} \mathrm{CFU}$ g1. Takođe, detektovana su i četiri mikotoksina kao što su aflatoksin B1 (AFB1), zearalenon (ZON), deoksinivalenol (DON) i fumonizin B1 (FB1). Mikotoksini AFB1 i FB1 detektovani su kao $100 \%$ pozitivni u svim ispitivanim uzorcima. Prosečna koncentracija AFB1 bila je 2,31 $\mu \mathrm{g} \mathrm{kg}^{-1} \mathrm{za} \mathrm{GS,} \mathrm{2,51} \mu \mathrm{g} \mathrm{kg}^{-1}$ za DS i 2,81 $\mu \mathrm{g} \mathrm{kg}^{-1}$ za SS, dok je prosečna koncentracija FB1 bila $1292,00 \mu \mathrm{g} \mathrm{kg}^{-1} \mathrm{za}$ DS, $1298,00 \mu \mathrm{g} \mathrm{kg}^{-1}$ za GS i $1902,00 \mu \mathrm{g} \mathrm{kg}^{-1}$ za SS. Prosečna koncentracija ZON toksina u pozitivnim uzorcima je $15,69 \mu \mathrm{g} \mathrm{kg}^{-1}$ za DS i $30,68 \mu \mathrm{g} \mathrm{kg}^{-1}$ za SS, dok njegovo prisustvo nije detektovano $\mathrm{u}$ uzorcima iz gornjeg sloja. Prosečna koncentracija DON toksina u pozitivnim uzorcima bila je od $41,71 \mu \mathrm{g} \mathrm{kg}^{-1} \mathrm{za}$ GS, $79,20 \mu \mathrm{g} \mathrm{kg}^{-1}$ za SS do $97,00 \mu \mathrm{g} \mathrm{kg}^{-1}$ za DS. Nije utvrđena statistički značajna korelacija sardžaja vlage sa ukupnim brojem plesni i koncentracijom pojedinih mikotoksina. Međutim, utvrđena je statistički veoma značajna korelacija između ukupnog broja plesni i koncentracije $\mathrm{AFB}_{1}(\mathrm{r}=1,0)$, $\mathrm{ZON}(\mathrm{r}=0,99)$ i $\mathrm{FB}_{1}(\mathrm{r}=$ $0,91)$, a nešto manja u slučaju DON i ukupnog broja plesni $(\mathrm{r}=0,54)$.

\section{References}

BENNET J.W., KLICH M. (2003): Mycotoxins. Clinical Microbiology Reviews 16, 3, 497-516.

BINDER E.M. (2007): Managing the risk of mycotoxins in modern feed production. Animal Feed Science and Technology, 133, 149-166.

BOTTALICO A. (1998): Fusarium diseases of cereals: Species complex and related mycotoxin profiles, in European Journal of Plant Pathology, 80, 85-103.

CLEVELAND T.E., DOWD P.F., DESJARDINS A.E., BHATNAGAR D., COTTY P.Y. (2003): United States Department of Agriculture - Agricultural research service Research on pre-harvest prevention of mycotoxins and mycotoxigenic fungi in US crops. Pest Management Science, 59, 629-642.

DRIEHUIS F., OUDE-ELFERINK S.J.W.H., SPOELSTRA S.F. (1999): Anaerobic lactate degradation in maize silage inoculated with Lactobacillus 
buchneri inhibits yeast growth and improves aerobic stability. Journal of Applied Microbiology, 87, 583-594.

ĐILAS, S., ŽIVKOV-BALOŠ , M., MIHALJEV, Ž, MRĐEN, M., MAŠ IĆ Z. (2001): Chemical, microbiological and mycotoxicological safety of animal diet mixes in the period from January 1999 to January 2000. Veterinarski glasnik, 1-2, 61-67.

EL-SHANAWANY A.A., EMAN MOSTAFA M., BARAKAT A. (2005): Fungal population and mycotoxins in silage in Assiut and Sohag governorates in Egypt, with special reference to characteristic Aspergilli toxins. Mycopathologia, 159, 281-289.

EUROPEAN COMMISSION (2006): Commision regulation (EC) No. 401/2006. Official Journal of the European Union, L70, 12.

FRISVAD J.C., THRANE U., SAMSON R.A., PITT J.L. (2006): Important mycotoxins and the fungi which produce them. Advances in Experimental Medicine and Biology, 571, 3-31.

GARON D., RICHARD E., SAGE L., BOUCHART V., POTTIER D., LEBAILLY P. (2006): Mycoflora and multimycotoxin detection in maize silage: experimental study. Journal of Agricultural and Food Chemistry, 54, 3479-3484. GONZÁLEZ-PEREYRA M.L., ALONSO V.A., SAGER R., MORLACO M.B., MAGNOLI C.E., ASTORECA A.L., ROSA C.A.R., CHIACCHIERA S.M., DALCERO A.M., CAVAGLIERI L.R. (2007): Fungi and selected mycotoxins from pre- and postfermented maize silage. Journal of Applied Microbiology, 104, 4, 1034-1041.

GONZÁLEZ-PEREYRA M.L., CHIACCHIERA S.M., ROSA C.A.R., SAGER R., DALCERO A.M., CAVAGLIERI L.R. (2011): Comparative analysis of the mycobiota and mycotoxins contaminating maize trench silos and silo bags. Journal of the Science of Food and Agriculture, 91, 8, 1474-1481.

HARLEY R.M. (1997): Mycotoxins in cereals. In: D'MELLO J.P.F. (ed), Mycotoxins and environmental health. The Scottish Agricultural College, West Mains Road, Edinburgh, UK.

LOGRIECO A., BOtTAliCO A., MulÉ G., MORETti A., PERRONE G. (2003): Epidemiology of toxigenic fungi and their associated mycotoxins for some Mediterranean crops. European Journal of Plant Pathology, 109, 645-667.

MARASAS W.F.O., ELLERMANN T.S., GELDERBLOM W.C.A., COETZER J.A.W., THIEL P.G., van der LUGT J.J. (1988): Leukoencephalomalacia in a horse induced by fumonisin B1 isolated from Fusarium moniliforme. Onderstepoort Journal of Veterinary Research, 55, 197-203.

MARQUARDT R.R., FROHLICH A.A. (1992): A review of recent advances in understanding ochratoxicosis. Journal of Animal Science, 70, 12, 3968-3988.

MILIĆEVIĆ D., NIKŠIĆ M., BALTIĆ T., VRANIĆ D. (2010): Isolation, characterization and evaluation of significant mycoflora and mycotoxins in pig feed from Serbian farms. World Journal of Microbiology and Biotechnology, 26, 9, 1715-1720. 
NOGAIM Q.A., AMRA H.A., BAKR A.A. (2011): Natural occurrence of mycotoxins in maize grains and some maize products. Pakistan Journal of Life and Social Sciences, 9, 1, 1-6.

OFFICIAL GAZETTE OF RS (2011): Regulation on amendment of Regulation on the maximum allowed residue levels of pesticides in food and animal feed for which maximum allowed residue quantities of plant protection products. No. 28 .

SRPS ISO 6496:2001 (2001): Animal feeding stuffs. Determination of moisture and other volatile matter content.

REDDY K.R.N., SALLEH B. (2011): Co-occurrence of moulds and mycotoxins in maize grains used for animal feeds in Malaysia. Journal of Animal and Veterinary Advanced, 10, 5, 668-673.

ROIGÉ M.B., ARANGUREN S.M., RICCIO M.B., PEREYRA S., SORACI A.L., TAPIA M.O. (2009): Mycobiota and mycotoxins in fermented feed, wheat grains and maize grains in Southeastern Buenos Aires province, Argentina. Revista Iberoamericana de Micología, 26, 4, 233-237.

SCOTT P.M. (2007): Analysis of ergot alkaloids - a review. Mycotoxin Research, 23, 3, 113-121.

SHIER W.T. (1998): Estrogenic mycotoxins. Revue de Médecine Vétérinaire 149, 6, 599-604.

SINOVEC Z., RESANOVIĆ R. (2006): Mycotoxins in food - risk for human health. Biotechnology in Animal Husbandry, 22, Special Issue, 705-716.

SRPS ISO 21527-1:2008 (2008): Microbiology of food and animal feeding stuffs Horizontal method for the enumeration of yeasts and moulds - Part 1: Colony count technique in products with water activity greater than 0,95 .

STATISTICAL OFFICE OF THE REPUBLIC OF SERBIA (2011): Statistical yearbook. Belgrade, pp. 413.

TARR, B. (2006): Managing the effects of molds and mycotoxins in ruminants. Shur-Gain, Nutreco Canada Inc.

WATANABE T. (1994): Pictorial atlas of soil and seed fungi. In: Morphologies of cultured fungi and key to species. Lewis Publishers, Boca Raton, Boston, London, Washington D.C. pp. 410.

WHITLOW L.W., HAGLER W.M. Jr. (2002): Mycotoxins in feeds. Feedstuffs, $74,28,68-78$. 